\title{
Nasopharyngeal Lymphoma in a developing Community
}

\author{
Wilson IB Onuigbo* \\ Department of Pathology, Medical Foundation and Clinic, Nigeria
}

Submission: December 18, 2018; Published: February 06, 2019

*Corresponding author: Wilson IB Onuigbo, Department of Pathology, Medical Foundation and Clinic, 8, Nsukka Lane, Enugu 400001, Nigeria

Abstract

The nasopharyngeal lymphoma has been reported from countries as far apart as China, Hong Kong, India, Korea, Morocco, Tunisia, and USA. Therefore, this report comes from Nigeria with special reference to the Ibo ethnic group. It was found that mostly young patients of either sex were involved. Follow-up data are not available.

Keywords: Nasopharynx; Lymphoma; Age; Nigeria; Ibos

\section{Introduction}

The nasopharynx is a commonly involved site of the lymphoma. Cases of it have been reported from countries as far apart as China [1-4], Hong Kong [5], India [6,7], Korea [8], Morocco [9], Tunisia [10], and USA [11]. Therefore, this paper deals with the Nigerian cases with special reference to the Ibo ethnic group [12]. This study was facilitated by the establishment of a Regional Pathology Laboratory such as the one canvassed by a Birmingham (UK) group as being of immense use in epidemiological analysis [13].

Table 1: Epidemiological data on nasopharynx lymphoma.

\section{Investigation}

As the pioneer pathologist in charge of the Regional Pathology Laboratory established in Enugu by the Regional Government, I was able to provide Histology Request Forms which stipulated the required epidemiological data. Moreover, as I kept personal copies of all the results, their analysis was facilitated as in this study.

\section{Results}

The tabular form is deemed to be practicable Table 1 .

\begin{tabular}{|c|c|c|c|c|c|}
\hline No & Initials & Age & Sex & Doctor & Diagnosis \\
\hline 1 & LE & 26 & F & Ezeanolue & Carcinoma \\
\hline 2 & EP & 15 & F & Mgbor & Tumor \\
\hline 3 & AC & 7 & M & Okoroafor & Carcinoma \\
\hline 4 & UC & 21 & M & Ezeanolue & Rhabdomyosarcoma \\
\hline 5 & NE & 60 & M & Udeh & Lymphoma \\
\hline 6 & KU & 5 & M & Ezeanolue & Carcinoma \\
\hline 7 & MM & 39 & M & Ezeanolue & Lymphoma \\
\hline 8 & OS & &
\end{tabular}

\section{Discussion}

The cohort consisted of 5 patients. It is clear that relatively young patients were involved. In this context, as the US authors generalized concerning nasopharyngeal malignancies in children, "They are, almost without exception, either lymphomas, rhabdomyosarcomas or nasopharyngeal carcinomas" [14]. Curiously, of the single case reports from India [6], and Korea [8], both were old. Indeed, in the publications dealing with numerous cases, the mean age was 46 years in China [3], 52.7 years in another Chinese report [9], and 59.3 years in USA [11]. In contrast, the local mean age is only 27 years. As for sex, our cohort showed male preponderance of 5 out of the 8 cases. The ratio was 84 males to 28 females in China [3].

Incidentally, unlike these series in which the treatment was at issue, as it was in China [1-4], the present paper differs. Thus, the practice here is to make the diagnosis available to the clinicians who provided the biopsy itself. The doctors were 
encouraged to even hazard a provisional diagnosis. Apparently, although all were impressed by the malignant disposition, only three correct diagnoses were made in terms of lymphoma.

\section{References}

1. Lei KI, Suen JJ, Hui P (1999) Primary nasal and nasopharyngeal lymphomas: A comparative study of clinical presentation and treatment outcome. Clin Oncol (R Coll Radiol) 11(6): 379-387.

2. Yuan ZY, Li YX, Zhao LI (2004) Clinical features, treatment and prognosis of 136 patients with primary non-Hodgkin's lymphoma of the nasopharynx. Zhonghua Zhong Liu Za Zhi 26(7): 425-429.

3. Zhang YJ, Ren ZM, Wu QL (2006) Treatment outcome and prognosis of 112 patients with nasal and nasopharyngeal peripheral T cell lymphomas. Zhongha Xue Ye Xue Za Zhi 27(4): 217-221.

4. Zou GR, Zhang YJ, Xie FY (2006) Prognosis and treatment strategies of primary B-cell and NK/T-cell nasopharyngeal non-Hodgkin's lymphoma at early stage. Ai Zheng 25(12): 1543-1549.

5. Cheung MM, Chan JK, Lau WH (1998) Primary non-Hodgkin's lymphoma of the nose and nasopharynx: Clinical features, tumor immunophenotype, and treatment outcome in 113 patients. J Clin Oncol 16(1): 70-77.

6. Nair RA, Jacob PM (2014) Nodal metastatic, undifferentiated nasopharyngeal carcinoma and classical Hodgkin lymphoma: Age old mimics. Indian J Pathol Microbiol 57(3): 507-509.
7. Lascar S, Muckaden MA, Bahl G (2006) Primary non-Hodgkin's lymphoma of the nasopharynx: Prognostic factors and outcome of $113 \mathrm{In}-$ dian patients. J Leukem Lymph 47(10): 2132-2139.

8. Kang JH, Park YD, Lee CH, Cho KS (2015) Primary mantle cell lymphoma of the nasopharynx: A rare clinical entity. Braz J Otorhinolaryngol 81(4): 447-450.

9. Allam W, Ismaili N, Elmaijaoui S (2009) Primary nasopharyngeal non-Hodgkin's lymphomas: A retrospective review of 26 Moroccan patients. BMC Ear Nose Throat Disord 9: 11.

10. Youssef YB, Bougmiza I, Bouabid Z (2012) Nasopharyngeal/nasal type NK/T lymphoma: Analysis of 23 cases and current review of the literature. Kulak Burun Bogaz Ihtis Derg 22(5): 275-283.

11. Han AY, Kuan EC, Alonso JE (2017) Epidemiology of nasopharyngeal lymphoma in the United Sates: A population-based analysis of 119 cases. Otolaryngol Head Neck Surg 156(5): 870-876.

12. Basden GT (1966) The Effective Power of Music in Africa. Scientific Research 5(3).

13. Macartney JC, Rollaston TP, Codling BW (1980) Use of a histopathology data pool for epidemiological analysis. J Clin Pathol 33(4): 351-355.

14. Bleichner JC, Ragsdale B, Hartmann DP, Merida M (1987) Nasopharyngeal malignancies in children. Ear Nose and Throat J 66(4): 30-41.

\section{Your next submission with Juniper Publishers will reach you the below assets}

- Quality Editorial service

- Swift Peer Review

- Reprints availability

- E-prints Service

- Manuscript Podcast for convenient understanding

- Global attainment for your research

- Manuscript accessibility in different formats

( Pdf, E-pub, Full Text, Audio)

- Unceasing customer service

Track the below URL for one-step submission https://juniperpublishers.com/online-submission.php 